\title{
Comparative Analysis of Agriculture Policies for Tobacco Planting and Processing, and the Correlation With the Illicit Production and Trade of Tobacco Products in Countries of the Western Balkans
}

\author{
Etleva Muça ${ }^{1} \&$ Fatmir Kazazi ${ }^{2}$ \\ ${ }^{1}$ AUT -Agricultural University of Tirana (ALBANIA), Tirana, Albania \\ ${ }^{2}$ Kazazi Consulting (ALBANIA), Tirana, Albania \\ Correspondence: Etleva Muça, AUT -Agricultural University of Tirana (ALBANIA), Tirana, Albania.
}

Received: September 11, 2020

Accepted: January 13, $2021 \quad$ Online Published: February 20, 2021

doi:10.5430/rwe.v12n2p248

URL: https://doi.org/10.5430/rwe.v12n2p248

\begin{abstract}
Tobacco planting and processing has a long tradition in the Western Balkan region, including Albania, Kosovo, Montenegro and North Macedonia; over the last 20 years, however, farmers have faced a significant decrease in production. In Montenegro and Kosovo, for example, the surfaces planted with tobacco are almost inconsequential.

Agricultural policies and legal and procedural frameworks regulate all related processes, such as tobacco seed distribution, registration of farmers, disclosure of land farmed for tobacco, production yield, and the various collecting and processing stages, as well as the enforcement capacities of the related law enforcement institutions. These factors have significantly impacted tobacco production and trade, including the levels of illicit production and trade.

This paper is based on empirical analysis, evaluation of the statistical data of tobacco-related state policies and country interviews related to tobacco production costs in the region, which affect sector-related policies.

Our findings indicate that Albania has a lack of clear and coordinated policies, procedures, and enforcement capacities to regulate and monitor all processes, from planting to the processing and trade of tobacco. North Macedonia is in a much better situation in this regard and a new draft tobacco law, associated with a series of implementation regulations is expected to result in further improvements. In the Albanian case, strong evidence suggests that there are considerable tracts of land planted with tobacco and many illegal tobacco-processing plants.
\end{abstract}

Keywords: tobacco, illicit trade, farmers, Western Balkans, tobacco policy

\section{Introduction}

\subsection{Main Situation}

The tobacco planting and production industry has a long tradition in the region, stretching over two centuries (Filiposki et al 2011), especially in relation to the oriental varieties. The best quality oriental and semi-oriental tobacco is traditionally produced in Balkan countries with favorable climate conditions for tobacco growing and which also are the main exporters of these tobaccos (Stojanoska 2014).

Over the last 20 years, the tobacco trade has undergone important changes in the four countries subject to our study. The land planted with tobacco in Montenegro and Kosovo has drastically decreased to reach irrelevant levels. Albania has also experienced a declining trend with many ups and downs; North Macedonia has bucked this trend, with the industry remaining one of the country's most important economic sectors (Tuna et al. 2014)

The general declining trend in tobacco cultivation in the region relates also to global changes and the shift of tobacco production towards developing countries, particularly India and Morocco, among others. Due to this situation the key research questions are: What are the main reasons that drive Western Balkan farmers towards illicit production? What are the effects of tobacco tax policies in the studied countries? 


\subsection{Sector Circumstances}

\subsubsection{Tobacco Production in West Balkan Countries}

Tobacco was previously considered an important crop for Western Balkan countries, with its high quality oriental and semi-oriental varieties (Stojanoska 2014). Such varieties do not require top-quality land and can be cultivated in poorer soils with cheap labor force, including women and older workers. This long tradition and experience, combined with favorable climate conditions enabled lower production costs and higher market competitiveness.

The traditional tobacco varieties in Western Balkan region are the oriental ones including Samsun, Izmir, Katerini, Krumovgrad, Prilep, Djebel, Sheldie, etc. They are usually grown on poor soil, in areas with plenty of sunny and warm days, which contributes to the formation of their strong aromatic and "sweet and sour" profile (Filiposki et al 2010).

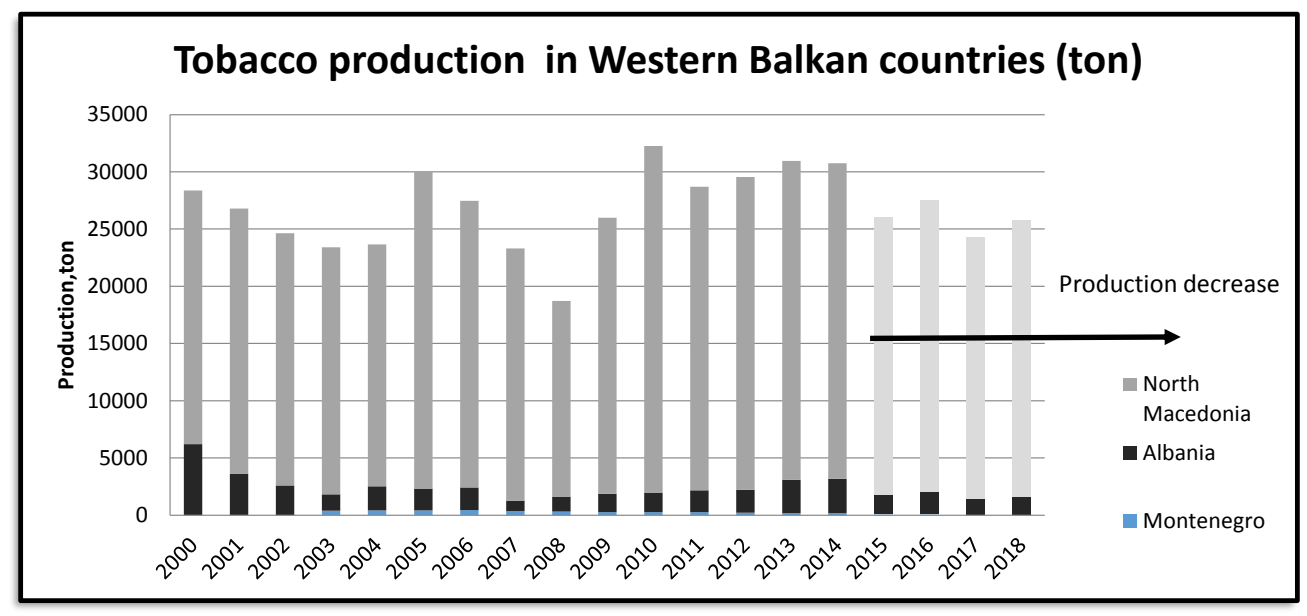

Figure 1. Tobacco production in Western Balkan countries

Source: INSTAT, Albania. North Macedonia statistics, Ministry of Agriculture of Kosovo Yearbook, MONSTAT 2019.

Tobacco planting in the Western Balkans is mostly dominated by small farms managed by individual farmers. Over the last five years, the main tobacco producer in the region has been North Macedonia (with an average of 23,000 25,000 hectares of land), followed by Albania (with an average of 2,000 hectares, out of which 40-50\% is used for illicit farming). During the period 1962 - 1990, Albania planted around 20,000 - 32,000 hectares with tobacco (Kyçyku 2015), but this has significantly decreased in the last 30 years (INSTAT 2019). So, through graphic 1 we can observe that:

- Tobacco planting has significantly decreased in Montenegro (MonStat 2019, Mugoša et al. 2018) and almost disappeared in Kosovo (MAFRD 2016);

- North Macedonia is the main producer of raw tobacco in the region, with certain ups and downs and a slight decreasing trend (MAKSTAT 2019) due to the good regulatory system, including financial subsidies;

- Albania remains statistically at an average level of 2,000-3,000 hectares, with significant ups and downs, but also has $40-50 \%$ illicit planting and production.

\subsubsection{Tobacco Export}

Western Balkan countries are mostly producers and exporters of the tobacco products (Stojanoska 2014). The export of leaf/raw tobacco has also faced strong variations within the region. 


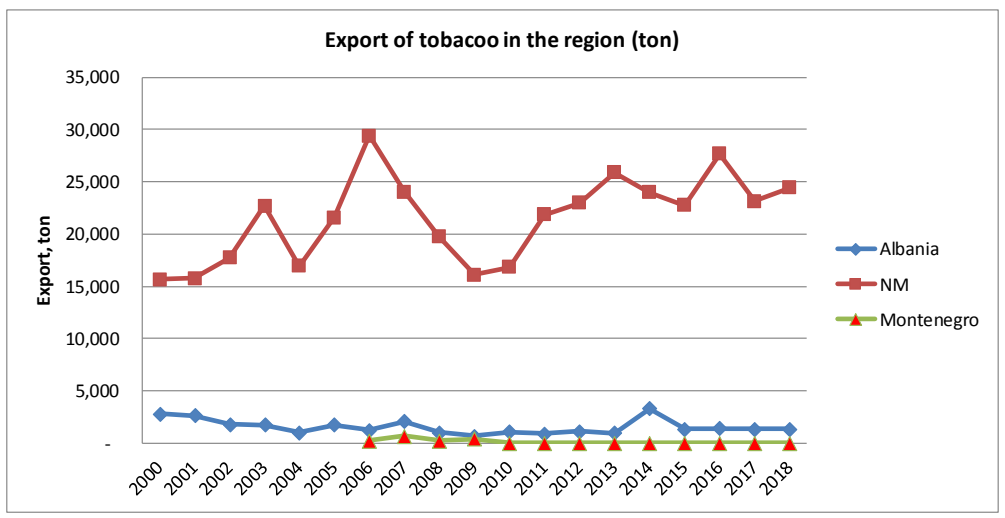

Figure 2. Tobacco export in Western Balkan countries

Source: Custom data, Albania, North Macedonia and Montenegro statistics 2019.

Figure 2 notes that:

- North Macedonia, with certain ups and downs, remains the main tobacco exporter in the region (MAKSTAT 2019)

- Albanian exports have decreased and remained at low levels, with considerable ups and downs (Custom Statistics of Albania 2019). Deeper analysis and interviews in Albania easily prove that there is considerable illicit production and export;

- In Montenegro, raw tobacco export has decreased to insignificant levels (Rajović \& Bulatović 2015), while in Kosovo it no longer exists (Mugoša et al. 2018)

1.2.3 Importation of Raw Tobacco, Processing, and Trade

The tobacco industry is among the most important economic sectors in the region, as seen in Table 1, below.

Table 1. Imported tobacco as raw material from regional countries

\begin{tabular}{lllllll}
\hline Regional countries & $\mathbf{2 0 1 3}$ & $\mathbf{2 0 1 4}$ & $\mathbf{2 0 1 5}$ & $\mathbf{2 0 1 6}$ & $\mathbf{2 0 1 7}$ & $\mathbf{2 0 1 8}$ \\
\hline Albania (ton) & 42 & 101 & 116 & 67 & 75 & 82 \\
\hline NM (ton) & 5,437 & 2,998 & 2,998 & 5,945 & 4,344 & 4,071 \\
\hline Montenegro (ton) & $\mathrm{n} / \mathrm{a}$ & $\mathrm{n} / \mathrm{a}$ & $\mathrm{n} / \mathrm{a}$ & $\mathrm{n} / \mathrm{a}$ & $\mathrm{n} / \mathrm{a}$ & $\mathrm{n} / \mathrm{a}$ \\
\hline Kosovo (ton) & $\mathrm{n} / \mathrm{a}$ & $\mathrm{n} / \mathrm{a}$ & $\mathrm{n} / \mathrm{a}$ & $\mathrm{n} / \mathrm{a}$ & $\mathrm{n} / \mathrm{a}$ & $\mathrm{n} / \mathrm{a}$ \\
\hline
\end{tabular}

Source: Custom Office Albania, North Macedonia

Despite the Western Balkan region being known as an important raw tobacco producer, unprocessed tobacco is still being imported, as it provides the mixtures required for cigarette production. Kosovo and Montenegro do not report data on import quantities of raw tobacco, since companies in those countries are bonded under a customs warehouse regime (Calderoni et al 2016) (or temporary import regime), but both have certain quantities of imported raw tobacco used only in the production of export-bound cigarettes. It is by leveraging this environment (e.g., bonded warehouse, inward processing, export warehouse, and excise warehouse) that these companies can import raw materials (both tobacco and non-tobacco) to produce and export the final goods (cigarettes) to other countries. In doing so, they generally avoid paying tax and customs duties. In any case, we believe that tobacco statistics should normally report these facts. 
Table 2. Cigarette production in the region

\begin{tabular}{lllllll}
\hline Regional countries & $\mathbf{2 0 1 3}$ & $\mathbf{2 0 1 4}$ & $\mathbf{2 0 1 5}$ & $\mathbf{2 0 1 6}$ & $\mathbf{2 0 1 7}$ & $\mathbf{2 0 1 8}$ \\
\hline Albania (ton) & 342 & 119 & 158 & 179 & 470 & 238 \\
\hline NM (ton) & 3,056 & 2,171 & 1,489 & 1,680 & 1,584 & 1,731 \\
\hline Montenegro (ton) & 830 & 844 & 767 & 362 & n/a & n/a \\
\hline Kosovo (ton) & n/a & n/a & n/a & n/a & n/a & n/a
\end{tabular}

Source: Custom Office Albania, North Macedonia, Montenegro and Kosovo. Authors' calculations

Table 2 presents cigarette production in the region and demonstrates a decreasing and volatile trend due to market changes within the region. Consumer smoking preferences are oriented towards international brands (Ken Research 2016) and processing companies are obliged to produce mostly for export purposes.

Table 3. The importation of cigarettes in the region

\begin{tabular}{lllllll}
\hline Regional countries & $\mathbf{2 0 1 3}$ & $\mathbf{2 0 1 4}$ & $\mathbf{2 0 1 5}$ & $\mathbf{2 0 1 6}$ & $\mathbf{2 0 1 7}$ & $\mathbf{2 0 1 8}$ \\
\hline Albania (ton) & 3,694 & 2,976 & 2,544 & 2,981 & 3,187 & 2,858 \\
\hline NM (ton) & 1,400 & 1,726 & 2,273 & 2,380 & 1,490 & 1,738 \\
\hline Montenegro* (ton) & 795 & 745 & 751 & 544 & 619 & 614 \\
\hline Kosovo (ton) & 3,048 & 2,973 & 2,814 & 2,982 & 2,755 & 2,856 \\
\hline
\end{tabular}

Source: Albanian, North Macedonia, Montenegro and Kosovo Custom; * WB 2019, Authors calculations

Comparing the custom data of tables 1,2, and 3, we can remark on certain discrepancies among the quantities imported as a raw material, domestic production, and the export/import of cigarettes. The above discrepancies, combined with the results of our surveys, lead to the conclusion that there are considerable levels of illicit tobacco production and trade.

\subsubsection{Tobacco Regulatory Framework}

The legal and procedural framework, which regulates all processes from tobacco seed distribution, farmers' registration, declaration of lands farmed with tobacco, production yield, and all collecting and processing stages, as well as related enforcement capacities have a significant impact in the levels of tobacco illicit production and trade. Such a regulatory framework shows a lack of implementation efficiency in Albania, whichseems to be more efficient in North Macedonia (MAFWE 2014).

Table 4, below, offers a general assessment based on our analysis and a series of interviews conducted in all countries included in the study with the state institutions responsible for drafting and implementing such regulations (including representatives from ministries of agriculture and finance, along with customs authorities, tobacco institutes, etc.), farmers and farmers associations, traders, and consumers.

Table 4. Tobacco industry framework

\begin{tabular}{lllll}
\hline Tobacco framework & Albania & Montenegro & Kosovo & North Macedonia \\
\hline $\begin{array}{l}\text { Law on tobacco and regulatory } \\
\text { framework }\end{array}$ & Yes & Yes & Yes & Yes \\
\hline Tobacco agencies & Yes & Yes & No & Yes \\
\hline Farmers' associations & Yes & Yes & No & Yes \\
\hline Tobacco processors & Yes & Yes & No & Yes \\
\hline Cigarette factories & Yes & Yes & Yes & Yes \\
\hline
\end{tabular}




\begin{tabular}{lllll}
\hline Subsidies for tobacco farmers & No & Yes & No & Yes \\
\hline $\begin{array}{l}\text { Government institutional } \\
\text { cooperation (Subsidies) }\end{array}$ & No & Yes & No & Yes \\
\hline Soil conditions for other plants & Poor & Poor & Poor & Poor \\
\hline Labour force costs & Low & High & Low & Low \\
\hline Illicit production and trade & Evident & Not significant & Evident & Not significant \\
& $40-50 \%$ & $10-15 \%$ & $10-15 \%$ & $5-10 \%$ \\
\hline
\end{tabular}

Source: Authors' estimation

The above-mentioned analysis and interviews led us to the conclusions that:

The regulatory framework and enforcement levels in Albania are in need of significant improvement;

The regulatory framework of Kosovo requires further development and completion;

In the case of Albania and Kosovo, state aid and subsidies (Zhllima \& Gjeçi 2015), (MAFRD 2016) related to tobacco planting should be considered;

In Montenegro, the regulatory framework regarding tobacco planting and processing is no longer efficient (MAFWE 2014) and needs improvement;

In North Macedonia the regulatory framework regarding tobacco planting, processing, and export has been more efficient and a new tobacco law, together with a series of new implementing instructions is expected to further improve the industry. The Tobacco Law notes that the funds to finance (support) tobacco production and the promotion of exports will be covered by the State Budget (MAFWE 2014). The tobacco industry is supported in various ways and by numerous measures. Guaranteed prices are set for the purchase of tobacco, in addition to financial support for tobacco purchasing companies and for the sold raw tobacco (MAFWE 2014).

\section{Literature Review}

The legal and procedural frameworks that regulate all processes, from tobacco seeds distribution to farmers' registration, declaration of lands farmed with tobacco, yield of production, and all collecting and processing stages, as well as the related enforcement capacities, have a significant impact on the levels of illicit tobacco production and trade. Illicit tobacco trade is among today's greatest global challenges, affecting not only our industry, but also governments and common people. It misleads consumers, deprives public authorities of tax revenue and funds organized crime and terrorism (PMI 2018).

Illicit Trade in Tobacco Products is any practice or conduct prohibited by law, and which relates to production, shipment, receipt, possession, distribution, sale or purchase, including any practice or conduct intended to facilitate such activity (WHO 2008). "The production, import, export, purchase, sale, or possession of tobacco goods which fail to comply with legislation" (FATF 2012-2019). Tobacco products are highly attractive for potential smugglers, mostly because of the high share of taxes in the final retail price, making them a highly profitable product to smuggle. A one euro increase in tax per pack in a country is expected to increase illicit market share by 5 to 12 percentage points and increase illicit cigarette sales by $25 \%$ to $120 \%$ of the average consumption (Prieger and Kulick 2016). Western Balkan countries continue to lose hundreds of millions of euros every year, because of the high level of illicit tobacco and cigarette production and trade. They are considered a good case study for the analysis of tobacco smuggling developed by the so-called Western Balkan smuggling route (Recher 2020).

There are many reasons and factors that create and impact changes in the illicit tobacco production and trade, but in Western Balkan countries the lack of a proper regulatory system and lack of advanced contracts with collectors and processors has led to a "self-regulating" system, deviating visibly toward illicit trade, especially in Albania.

\section{Method}

The tobacco sector has a big impact not only on agricultural activity but also on the economies of the Western Balkan countries due to the long tradition in tobacco production and trade (Mikulic and Buturac 2020).

This paper analyses the statistical data and related regulatory frameworks of tobacco production and trade in the region, as well as information collected through a series of direct meetings, workshops, surveys, and interviews with professionals in responsible state institutions, producers, traders, and consumers. The research was undertaken as part 
of the PMI Impact Albania Project entitled "Correlation between tax burden and illicit trade and corruption".

Statistical data was collected at both national and local level, with figures provided by numerous official bodies (including ministries of agriculture, statistics institutes, regional agriculture directorates, municipalities and communes) and the respective tobacco institutions.

The secondary data are taken from the municipalities and administrative units of the region respectively:

1. In Albania from the municipality of Belsh, Cerrik, Malesi, and Madhe.

2. The Municipality of Tuz in Montenegro.

3. The Kosovan municipality of Gjilan.

4. In NM from the municipality of Prilep.

Primary data are taken from face-to-face interviews from three countries - Albania, NM, and Montenegro during May and July 2018. Kosovo was not included in the process since tobacco is no longer produced there (KAS 2016). The interviews were random and conducted with small tobacco producers, taking place in the following districts: Elbasan, Shkodër, and Korça in Albania, Tuz in Montenegro, and Prilep and Kumanovo in NM. The main purpose of these face-to-face interviews was to assess the farming areas dedicated to tobacco cultivation, the amounts actually produced, including reported and unreported numbers, along with the number of registered and unregistered farmers, etc. The interviews and visits to farming, processing, and production sites enabled us to validate the accuracy of the reported data and clarify our findings on the levels, types, and purposes of illicit production and trade. The face-to-face interview was considered the best method since it provided us the possibility to obtain more complete information and results than other survey methods (Dillman 1989, Babbie 2007).

We have applied a comparative-analytical method for country data processing and in drawing conclusions and making recommendations. "Thinking without comparison is unthinkable. And, in the absence of comparison, so is all scientific thought and scientific research" (Ragin 1987).

\section{Results}

Our analysis consisted of the evaluation and measurement of the data, in addition to the assessment of the problems encountered by farms cultivating tobacco as evidenced via official statistics, but also through direct meetings with farmers, farmers' associations, processors and traders, tobacco agencies, and other related state institutions. It must be emphasized that official statistics are often contradictory and inefficient. A survey with farmers helped us evaluate the situation.

Table 5. Tobacco farm circumstances in the interviewed areas

\begin{tabular}{llllllll}
\hline & $\begin{array}{l}\text { No. } \\
\text { question. }\end{array}$ & $\begin{array}{l}\text { Average } \\
\text { farm size } \\
(\mathrm{Ha})\end{array}$ & $\begin{array}{l}\% \text { of } \\
\text { cultivated } \\
\text { tobacco in rapport } \\
\text { with other cultures }\end{array}$ & $\begin{array}{l}\text { Quantity } \\
\text { sold } \\
\text { black } \\
\text { market }(\%)\end{array}$ & $\begin{array}{l}\text { Financial } \\
\text { support from } \\
\text { government } \\
(\%)\end{array}$ & $\begin{array}{l}\text { Contracts } \\
\text { with } \\
\text { processing } \\
\text { industries }\end{array}$ \\
\hline Montenegro & 22 & 1.58 & 63 & 14 & 92.4 & 100 \\
\hline $\begin{array}{l}\text { North } \\
\text { Macedonia }\end{array}$ & 50 & 1.74 & 57 & 7 & 95.5 & 100 \\
\hline Albania & 151 & 1.1 & 54 & 46 & 0 & 74 \\
\hline
\end{tabular}

Source: Authors' estimation

All interviewed farmers are tobacco cultivators; they own of smallholdings of 1.7 Ha in North Macedonia, 1.5 Ha in Montenegro, and 1.1 Ha in Albania. Tobacco is usually planted on half of their land, with the rest reserved for fruit and vegetables. Of all those interviewed only the farmers in the Elbasan area had contracts; Farmers in the Shkodra district were not aware of the importance of contracting. This fact was also linked to government policies and regulations and related uncertainties, since in Albania farmers do not profit from public subsidies. Non-supported farmers in North Macedonia and Montenegro accomplish none of the criteria set by their respective governments. 


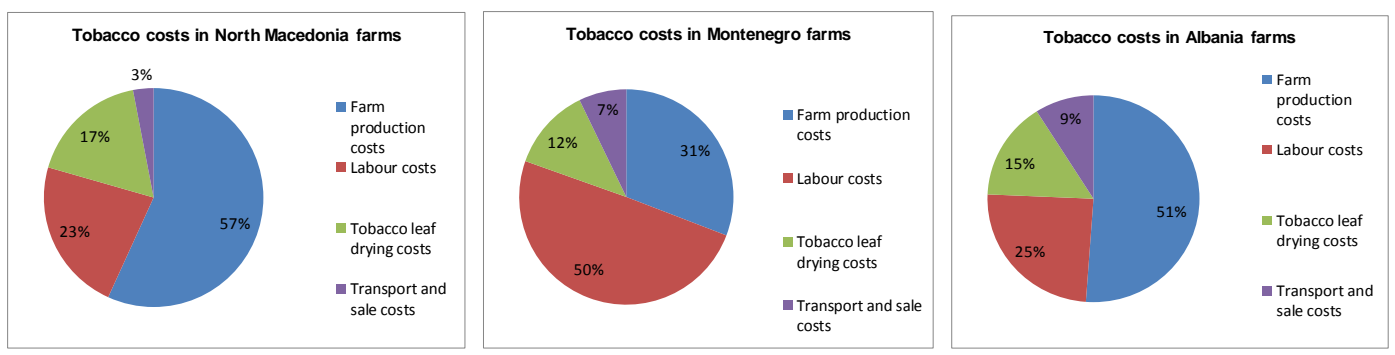

Figure 3. Tobacco costs in the region

Source: Authors' estimation

Another element affecting tobacco cultivation sustainability is related to the planting cost structure and profitability. Figure 3 explains the tobacco cost structure for each country. We can observe that in North Macedonia tobacco cultivation costs remain at the same logic with the costs of other products. On the other hand, some types of cost are eliminated such as the payments for the seeds or those related to the sale of products.

The tobacco contractual price from processing companies is almost the same for all studied regions in Montenegro, Albania, and North Macedonia.

Table 6. Tobacco producers cost benefit report

\begin{tabular}{llll}
\hline Reports & Albania & North Macedonia & Montenegro \\
\hline Costs/Final price & $64.3 \%$ & $73 \%$ & $72.4 \%$ \\
\hline (Costs-Subsidies)/Final price & $64.3 \%$ & $39.7 \%$ & $58.6 \%$ \\
\hline
\end{tabular}

Source: Authors' estimation

As we can observe from table 6, the difference is clear only from subsidy support for tobacco producers. Albania is facing a higher cost level for the same market product since it does not profit from public subsidies. In Albania, according to EU regulation for tobacco, regime farmers are not granted any specific subsidy for raw tobacco production (EU 2013). As a result, Albanian farmers are not interested in selling their products to processing companies since their profit is low.

Thus, both registered and illegal farmers do not report all produced quantities, and considerable parts of production are illicitly sold to domestic producers, with certain quantities even being sent to neighbouring countries (mostly Montenegro).

In North Macedonia, farmers are not greatly affected by competition due to advanced contracts with contracting companies; in addition, the industry is well-regulated and tobacco laws are implemented. As mentioned, most of the production is contracted in advance, although some farmers grow without reporting the quantities they produce (semi-oriental tobacco), preferring instead to sell it directly to the market as fine-cut tobacco. In this case, tobacco is sold to people who have cutting tools and other equipment to finely cut its leaves and then resell it at green markets. The government "somehow" tolerates this activity, because the product is freely sold at local green markets. This type of illicit tobacco may account for about $5 \%$ of the domestic tobacco market share.

Meanwhile in Montenegro we observe high harvesting costs, which are causally related to labor force costs. This disadvantage is reflected in the decreased number of tobacco cultivators. Recently, farmers from the Shkodra region (Albania) were employed but the problem persists. The tobacco association is attempting to revitalize this practice, but the situation remains unchanged.

Furthermore, Albania contends with high tobacco cultivation costs and a large number of farmers plant tobacco without advance contracts, their yield thus being mostly illicit. Non-contracted farmers can earn more by selling in local illicit markets at higher and more competitive prices (since no taxes are paid). Under these conditions the Albanian results show a higher level of illicit tobacco. The questionnaires conducted in Albania with farmers, and the data gathered during direct visits to the main tobacco cultivation areas, offer a detailed picture about the land used for 
tobacco and related processing capacities. We compared the statistical data from different Albanian institutions and collection companies with our field research and the results show that about half of the land in Albania used for tobacco cultivation is illicit. There it is illicitly sold as a raw material or fine cut tobacco on the domestic market but also exported to foreign markets, mostly via Montenegro.

Table 7. Evaluation of Albanian land surfaces cultivating tobacco in 2018

\begin{tabular}{llll}
\hline & $\begin{array}{l}\text { Tobacco cultivated } \\
\text { surface }(\mathrm{ha})\end{array}$ & $\begin{array}{l}\% \text { of the farm } \\
\text { surface } \\
\text { with tobacco } \\
\text { cultivated }\end{array}$ & $\begin{array}{l}\text { Tobacco production } \\
\text { (tons) }\end{array}$ \\
\hline National Agency of Tobacco & 1,018 & $29 \%$ & 1,578 \\
\hline $\begin{array}{l}\text { Tobacco collection } \\
\text { companies (Note 1) }\end{array}$ & 377 & $31 \%$ & 490 \\
\hline $\begin{array}{l}\text { Evaluation according field } \\
\text { interviews }\end{array}$ & 1,978 & $56 \%$ & 3,383 \\
\hline
\end{tabular}

Source: Albanian Tobacco Agency, collection companies, field interviews

According to the questionnaires conducted with farmers and collection companies, we re-evaluated the amount of land declared for tobacco cultivation in Albania. The method followed in this re-evaluation was carried out in comparison to individual visits to villages that reported tobacco cultivation. Following this correction, the real cultivated area in 2018 was 1978 hectares, producing 3383 tons of tobacco leaves. Meanwhile, the official numbers reported by the National Agency of Tobacco showed only 1018 hectares and a production of 1578 tons. This clearly demonstrates that almost $50 \%$ of the tobacco produced in Albania is not declared.

In conclusion we can state that all of land where domestic varieties (semi-oriental tobacco) are grown, is cultivated for illicit purposes, since tobacco companies are not interested in those varieties. On the other hand, companies that used fine cut tobacco for the domestic trade in 2018 declared only 12 tons (around 8 hectares). Thus, the difference in data between contracted tobacco and that which is undeclared to the Albanian customs office is evaluated by this study as illicit.

\section{Discussion}

Tobacco production and trade is clearly a dual market, consisting of a legal and an illegal part. Demand and consumption are therefore covered by both licit and illicit suppliers that, either directly or indirectly, are connected to or influence the business decisions of each other. Actions taken from one side of the market, influence the other side and both considerably impact the efficiency of the state economic and tax policies. Sometimes the same operators engage in both licit and illicit production and trade of tobacco.

In North Macedonia tobacco cultivation and processing is considered one of the main agricultural sectors and has a comprehensive regulatory framework and efficient support by the State. Montenegro, Kosovo, and Albania in particular, have weaker regulatory frameworks and implementation capacities.

Illicit tobacco production and trade has been the result of a legal and procedural framework that regulates all processes from tobacco seed distribution, registration of farmers, declaration of lands farmed for tobacco, production yield, and all collecting and processing stages, in addition to related enforcement capacities.

In Albania, the lack of a proper regulatory framework in the production of tobacco and tobacco products, combined with weak administrative and enforcement powers, has led to a much higher level of informality compared with North Macedonia. This is despite both countries having a similar economic development level and a tradition and culture of growing tobacco.

- These areas have a long experience and tradition in producing high quality oriental tobacco, which should not be allowed to be lost; therefore efficient measures in agricultural and tax policies should be taken, especially in Kosovo and Montenegro.

- For Albania and North Macedonia tobacco is an export-oriented product, which generates significant earnings for the economy of both countries. Albania needs drastic measures and improvements in its tobacco regulatory 
framework and enforcement efficiency in order to use its related natural and human resources more resourcefully to increase tobacco production and export.

- The tobacco market remains uncertain, especially for Albanian farmers, as it is not well defined, since it is characterized by small land surface, fragmented land, high production costs, and a lack of rules in terms of collecting and processing operators, etc. The governments of Macedonia and Montenegro support tobacco growers, since the sector is considered to be particularly important for the economy. Farmers are the first link in the tobacco value chain, so it is crucial to support them not only to just achieve a sustainable livelihood. Furthermore, it is important to create strong rules and provide evidence about farming and the production of tobacco in order to fight illicit production and trade more easily. On the other hand, in Kosovo and Albania tobacco is not seen as an important sector. The Albanian national strategy mentions the tobacco industry just once, which proves its significance (MARDWA 2014). Agriculture specialists engaged in the strategy have even neglected to analyze the National Tobacco Agency (MARDWA 2014). The lack of capacity and information coming from the Albanian government today has resulted in one of the most informal and illicit markets in the region. Often, farmers pay "municipality taxes" for space in markets at which they sell illicit tobacco. In other words, municipalities often "consider" the fine cut tobacco sold in open markets to be legal, just like vegetables and fruit, although the former should be subject to excise tax and VAT.

- One of the main problems in the tobacco processing industry, particularly for Albania, is the lack of evidence and clarity in reporting. Cross-checking the information from third parties leads to the conclusion that there is considerable illicit production and trade.

- Export data is unclear for Kosovo since customs declares a lack of exports, despite the tobacco company in Gjilan producing cigarettes only for export.

\section{Acknowledgements}

The realization of this study was made under PMI support.

\section{References}

Babbie, E. R. (2007). The practice of social research (11th ed.). Belmont, CA: Wadsworth Publishing.

Calderoni, F., Brener, A., Karayotova, M., Rotondi, M., \& Zorč, M. (2016). The Eastern Balkan Hub for Illicit Tobacco. Trento, Italy: Transcrime-Università degli Studi di Trento. Retrieved from http://www.transcrime.it

Custom Statistics of Albania. (2019). Publikime. Retrieved from http://www.dogana.gov.al/c/171/225/publikime

Dillman, D. A. (1989). Our changing sample survey techniques. Choices, 4(4).

EU. (2013). Regulation (EU) No 1308/2013 of the European Parliament and of the Council of 17 December 2013 Establishing a common organisation of the markets in agricultural products and repealing Council Regulations (EEC) No 922/72, (EEC) No 234/79, (EC) No 1037/2001 and (EC) No 1234/2007. Retrieved from http://data.europa.eu/eli/reg/2013/1308/2019-01-01

FATF. (2012-2019). International standards on combating money laundering and the financing of terrorism \& proliferation. FATF, Paris, France. Retrieved from www.fatf-gafi.org/recommendations.html

Filiposki, K., Pesevski, M., Ralevic, N., \& Kabranova, R. (2010). Production of oriental tobacco in the Balkan countries. Tymyн/Tobacco, 60(7-12), 94-102.

Filiposki, K., Peshevski, M., Živković, D., \& Filiposki, B. (2011). State of Tobacco Production in the Republic of Macedonia. Retrieved from http://www.agrosym.rs.ba/agrosym/agrosym_2011/pdf/Agricultural_economics/Filiposki_et_al.pdf

INSTAT. (2019). Statistical yearbook of Albania. Retrieved from www.instat.gov.al

KenResearch. (2016). Cigarettes in Macedonia. Retrieved from https://www.kenresearch.com/blog/2016/10/cigarettes-in-macedonia/

Kosovo Agency of Statistics (KAS). (2016). Crop production in Kosovo 2014. Retrieved from https://ask.rks-gov.net/media/2476/kulturat-e-arave-ne-republiken-e-kosoves-2016.pdf

Kyçyku, K. (2015). Effects of genetic and technologic improvement in the production and quality of the oriental tobacco variety. PhD Thesis, Agriculture University of Tirana. Retrieved from www.ubt.edu.al

MAKSTAT. (2019). Macedonia in Figures. Publication of Macedonian Institute of Statistics. Retrieved from http://www.stat.gov.mk 
MARDWA. (2014). Inter-Sectorial Strategy for Agriculture and Rural Development (ISARD 2014-2020). Tirana, Albania 2014.

Mikuli, C. D., \& Buturac, G. (2020). In what measure is public finance sustainability threatened by Illicit Tobacco trade: The case of Western Balkan Countries. Sustainability, 12(1), 401. https://doi.org/10.3390/su12010401

Ministry of Agriculture, Forestry and Rural Development (MAFRD). (2016). Green Report of Kosovo 2016. Retrieved from https://www.mbpzhr-ks.net/repository/docs/Raporti_i_Gjelbe776rt_2016_Shqip_Final.pdf

Ministry of Agriculture, Forestry and Water Economy (MAFWE). (2014). National Strategy for Agriculture and Rural Development for the period 2014-2020. Skopje, November 2014.

Ministry of Agriculture, Forestry and Water Management (MAFWE) in Montenegro. (2014). Montenegro's Agriculture and European Union. Agriculture and Rural Development Strategy. Podgorica, Montenegro, 2014

Mugoša, A., Popović, M., Laković, T., \& Čizmović, M. (2018). Accelerating Progress on Effective Tobacco Tax Policies in Low- and Middle-Income Countries, National Study - MONTENEGRO. Economics of Tobacco and Tobacco Taxation. Institute of Socio-economic analysis, Podgorica, Montenegro 2018.

PMI. (2018). Fighting illicit trade in Tobacco products.

Prieger, J. E., \& Kulick, J. (2016). Cigarette taxes and illicit trade in Europe. https://doi.org/10.2139/ssrn.2718519

Ragin, C. (1987). The Distinctiveness of Comparative Social Science. In The Comparative method: moving beyond qualitative and quantitative strategies. University of California Press. Retrieved from http://www.jstor.org/stable/10.1525/j.ctt1pnx57.5

Rajović, G., \& Bulatović, J. (2015). Structural changes of plant production in Montenegro (2003-2012): a review. World Scientific News, 12, 111-124.

Recher, V. (2020). Illegal tobacco demand: The case of Western Balkan. Economic Analysis and Policy, 66, 182-193. https://doi.org/10.1016/j.eap.2020.04.001

Statistical Office of Montenegro. (2019). Statistical yearbook. Retrieved from www.monstat.org

Stojanoska, S. (2014). Dynamic presentation of the oriental and semi-oriental tobacco production in the Balkan countries and in the Republic of Macedonia. Tymyн/Tobacco, 64(1-6), 62-69.

Tuna, E., Georgiev, N., \& Nacka, M. (2013). Competitiveness analysis of the tobacco sub-sector in the Republic of Macedonia. Agroeconomia Croatica, 3(1), 53-60.

WHO. (2008). Report on the global tobacco epidemic: The MPOWER package 2008. Geneva, Switzerland: World Health Organization; 2013. Retrieved from http://www.who.int/tobacco/mpower/mpower_english.pdf

World Bank Group. (2019). Montenegro: overview of tobacco use, tobacco control legislation, and taxation a country brief. Global tobacco control program, Country brief.

Zhllima, E., \& Gjeçi, G. (2015). Albania: agricultural policy brief (CAPB). European Commission Publication. Retrieved

from http://app.seerural.org/wp-content/uploads/2016/11/2015-10_Country-policy-brief-Albania-Final.compressed.pdf

\section{Note}

Note 1 . We have preliminary data from one tobacco collection company with the aim of identifying the operating area and farm percentage cultivated with tobacco.

\section{Copyrights}

Copyright for this article is retained by the author(s), with first publication rights granted to the journal.

This is an open-access article distributed under the terms and conditions of the Creative Commons Attribution license (http://creativecommons.org/licenses/by/4.0/). 